\title{
African swine fever virus DNA detection in commercial pig feed and feed ingredients in China
}

\author{
Zhichun Yan ${ }^{1}$, Yakuan Huang ${ }^{1}$, Gordon Spronk ${ }^{1}$, and Scott Dee ${ }^{2}$
}

${ }^{1}$ Affiliation not available

${ }^{2}$ Pipestone Veterinary Services

November 25, 2020

\begin{abstract}
During the acute phase of the African Swine Fever Virus (ASFV) epidemic in China, complete feed, and feed ingredients from three mills were tested for ASFV DNA by PCR. Across mills, the percentage of positive sample pools detected in complete feed ranged from $0.5 \%$ to $1.2 \%$, and from $0.2 \%$ to $1.8 \%$ in feed ingredients, including positive pools of wheat, rice, corn, and soy samples. This is the first report of ASFV contamination in feed under commercial conditions in China.
\end{abstract}

\section{Hosted file}

ASFV in feed FINAL.pdf available at https://authorea.com/users/378594/articles/495045african-swine-fever-virus-dna-detection-in-commercial-pig-feed-and-feed-ingredients-inchina

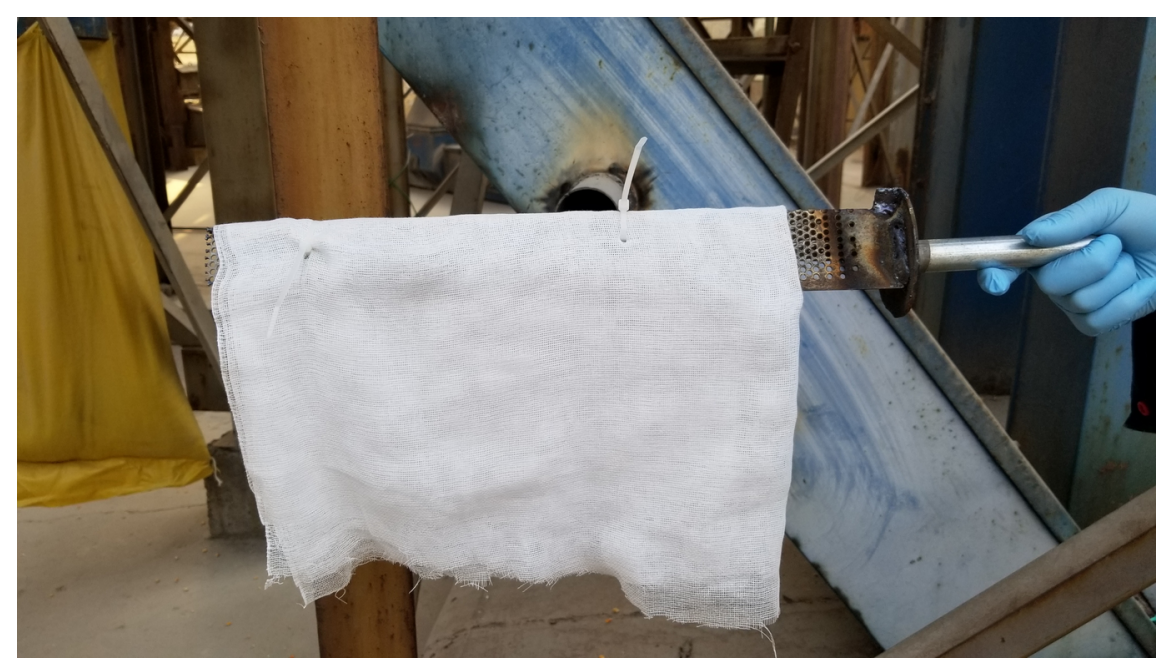

